\title{
Phytoremediation and Carbon Sequestration Potential of Agroforestry Systems: A Review
}

\author{
Khanzad Gul Zazai, Owais Ali Wani*, Aamina Ali and Mamta Devi \\ SKUAST- J, J\&K -180009, India \\ *Corresponding author
}

\section{A B S T R A C T}

\begin{tabular}{l} 
K e y w o r d s \\
$\begin{array}{l}\text { Phytoremediation, } \\
\text { Carbon sequestration, } \\
\text { Agroforestry systems, } \\
\mathrm{CH}_{4} \text { sinks, Climate } \\
\text { change }\end{array}$ \\
\hline Article Info \\
\hline $\begin{array}{l}\text { Accepted: } \\
\text { 16 December } 2017 \\
\text { Available Online: } \\
\text { 10 January } 2018\end{array}$ \\
\hline
\end{tabular}

\section{Keywords}

Agroforestry systems,

$\mathrm{CH}_{4}$ sinks, Climate

Article Info

Accepted:

10 January 2018
Agroforestry constitute major chunk of share in replenishing atmosphere, sequestering carbon, and remediating contaminated soils. Phytoremediation is emerging as an alternative agriculture-based technology because word remediation of metal polluted sites can be brought about utilizing the plants to uptake and store contaminants in them. Conventional procedures for cleaning up heavy-metal- contaminated sites (i.e. excavation, dredging, and chemical leaching) are all expensive and destructive for the natural environment. An alternative to these physical remediation methods is the use of plants to remove pollutants from soil and water through their root systems, an approach known as phytoremediation. Once extracted, plants may sequester the pollutants in their tissues and/or convert them to less toxic forms. Agroforestry systems are a better climate change mitigation alternatives than oceanic, and other terrestrial options because of the secondary environmental benefits such as helping to attain food security and secure land tenure in developing countries, increasing farm income, restoring and maintaining above-ground and below-ground biodiversity, corridors between protected forests, as $\mathrm{CH}_{4}$ sinks, soil conservation and. maintaining watershed hydrology.

\section{Introduction}

Contaminants of concern are both inorganic and organic compounds (heavy metals, radionuclides, nitrate, phosphate, inorganic acids, and organic chemicals) from sources including waste materials, explosives, pesticides, fertilizers, pharmaceuticals, acidic deposition, and radioactive fallout. Soil, surface water, and groundwater may become contaminated with hazardous compounds as a consequence of natural activities (e.g., geologic erosion and saline seeps) and human activities (e.g., industry, agriculture, wastewater treatment, construction, and mining). Pollutants may be traced to a particular source, point source, or result from a large area, nonpoint source. Both in situ and ex situ remediation methods have been employed to remove contamination, most relying on physical and chemical processes. In situ methods include volatilization via air venting, leaching with a surfactant, vitrification (contaminants are solidified with an electric current) and isolation and containment with physical barriers (Sparks, 1995). Ex situ methods include excavation followed by thermal treatment, chemical 
extraction, and/or solidification (encapsulation) prior to disposal in a landfill. Phytoremediation, the use of plants to bioremediate contaminated soil, water, and air, has emerged as a more cost effective, noninvasive, and publicly acceptable way to address the removal of environmental contaminants (Boyajian, 1997). An overview of phytoremediation, including phytofiltration and rhizofiltration, phytoextraction, phyto immobilization, phytostabilization and phytodegradation, and rhizodegradation, is presented in this review. Biotechnological advances in phytoremediation are also discussed. These modern tools provide insight into processes important to phytoremediation and allow for the optimization of phytoremediation, improving its commercial viability.

\section{Rhizofiltration and phytofiltration}

Phytofiltration or rhizofiltration is the use of plants to remove contaminants from water. The plant can take up contaminants into the biomass, thus removing the pollutant. Rhizofiltration is a form of phytoremediation, which refers to the approach of using hydroponically cultivated plant roots to remediate contaminated water through absorption, concentration, and precipitation of pollutants (Raskin and Kumar, 1994). PilonSmits et al., (1999) identified several species, including parrot's feather (Myriophyllum brasiliense), iris-leaved rush (Juncus xiphioides), cattail (Typhalati folia), saltmarsh bulrush, and Scirpusrobustus, that showed great potential for Se phytoremediation in wetlands. De Souza et al., (1999) determined that bacteria in the rhizosphere of Indian mustard (Brassica juncea) were necessary to achieve the best rates of plant Se accumulation and volatilization of selenate. A novel phytofiltration technology has been proposed by Sekhar et al., (2004), which could be used to remove and recover lead $(\mathrm{Pb})$ from wastewaters. This technology uses plant based biomaterial from the bark of the plant commonly called Indian sarsaparilla (Hemidesmusindicus). The target of their research was polluted surface water and groundwater at industrially contaminated sites. Rhizofiltration of lead-contaminated water has also been investigated by Schulman, Salt, and Raskin (1999).

\section{Phytostabilization and Phytoimmobilization}

Phytostabilization results in the elimination of the availability of toxic metals in soil through complexing with metals by certain plants (Gwozdz and Kopyra, 2003). This process does not remove the contaminant from the soil, but it does reduce the inherent hazard of the contaminant ( $\mathrm{Li}$ et al., 2000). Phytoimmobilization is a remediation technology in which plants are used to remove contaminants from soil through plant uptake and subsequently the contaminants are released from decomposing plant materials and are then immobilized in either a mineralamended soil or a geomat (mineral-containing mat). This strategy is being evaluated at the Savannah River Site in Aiken, S.C., by researchers who are investigating indigenous plants that have the natural ability to accumulate high concentrations of contaminants (Knox et al., 2001).

\section{Hyperaccumulation and phytoextraction}

Phytoextraction, the ability of plants to take up inorganic (primarily metal) contaminants from soil is becoming a more widely-used remediation technology (McCutcheon and Schnoor, 2003). The most common route of chemical uptake into plants is through the root via an aqueous phase. Ions and organic molecules move to roots from soil and sediment through plant transpiration (ion transport from the soil water into the root occurs simultaneously with water transport), 
diffusive transport, and microbial facilitated transport (Committee on Bioavailability of Contaminants in Soils and Sediments, 2003). The plasma membrane serves as a barrier to uptake; chemicals need to cross the plasma membrane into the cytoplasm of the root cells. Different mechanisms have been identified which control chemical uptake by plants. Some chemicals can enter root tissue by altering $\mathrm{pH}$ through efflux of hydrogen $(\mathrm{H}+)$ ions, resulting in an electrochemical gradient that facilitates transport of cations and anions. This mechanism is termed a proton pump and requires cellular energy in the form of adenosine triphosphate (ATP). Most divalent cations are absorbed through ion channels. Ion channels can also mediate uptake and release potassium ions $(\mathrm{K}+)$. There is also evidence for carrier-mediated active transport of $\mathrm{K}+$, $\mathrm{SO}_{2}-4, \mathrm{NO}-3$, and $\mathrm{Mg}^{2+}$ that uses ATP as an energy source (Marschner, 1995). For metals, another possible mechanism of uptake is transport of metal-chelate complexes. Whenever there is a metal deficiency, plants produce and release chelating agents into the rhizosphere. The complexed metal form is then transported into the plant through a transport protein specific for that metal (Kochian, 1993; Von Wiren, Marschner, and Romheld, 1996).

\section{Phytodegradation and rhizodegradation}

Degradation of a compound refers to its breakdown into smaller constituents, or its transformation to a metabolite. It is important to identify, quantify, and understand the significance of metabolites formed during remediation because of their potential unknown toxicities and availabilities to biota. Rhizodegradation, or transformation of the contaminant in the rhizosphere, can occur in soil organisms such as fungi or bacteria, or via enzyme exuded from microorganisms or plants.

\section{Phytodegradation}

Methods for studying phytodegradation can involve growing plants in soils, nutrient media in hydroponic systems, or utilization of tissue preparations (Bhadra et al., 2001). In a hydroponic system, the solution is treated with a known concentration of the contaminant in question, and plant uptake, metabolism, and exudation are studied.

\section{Rhizodegradation}

The rhizosphere, with myriad species of microorganisms from many taxa, is a perfect example of biodiversity. While any individual species is usually capable of producing one or more enzymes that can carry out a biotransformation reaction, a consortium of microbes in the root zone of a plant can carry out many and varied types of enzymatic transformations (Anderson, Guthrie, and Walton, 1993).

\section{Degradation is influenced by variable factors}

Phytodegradation and rhizodegradation proceed via enzymatic activity; there are numerous other variables that influence the process, including soil temperature, moisture, $\mathrm{pH}$, organic matter content, and aeration, all of which can affect the proliferation of microorganisms in the soil, which in turn will affect biodegradation. There are also factors from the biological perspective that can modify the contaminant and it degradates in a phytoremediation setting. It is crucial to understand the physical, chemical, and biological processes, as well as interactions between them, before we can optimize conditions for phytoremediation or have confidence in making predictions about the potential extent or rate of cleanup from a phytoremediation approach to a given soilcontamination situation. 


\section{Transformation pathways}

Transformation of contaminants can occur through a variety of pathways. In this case, we will discuss the metabolism and cometabolism of pesticides, as example compounds. Plants and soil microorganisms, including bacteria and fungi, contain many similar enzymes for detoxification or transformation of xenobiotics. One major difference between microorganisms and higher plants is that microbes are much more likely to mineralize a contaminant (Hoagland et al., 2001) or use it as a nitrogen source (Assaf and Turco, 1994).

\section{Improving phytoremediation with biotechnology}

Transfer of metabolic functions from microorganisms to plants

Exploitation of the inherent detoxification mechanisms of plants

Transfer of metabolic functions from mammals to plants

\section{Carbon sequestration potential in agroforestry systems}

Management of trees in agro-ecosystems such as agroforestry, ethno forests, and trees outside forests can mitigate greenhouse gas (GHG) emissions under the Kyoto Protocol. Agroforestry systems are a better climate change mitigation option than oceanic, and other terrestrial options because of the secondary environmental benefits such as helping to attain food security and secure land tenure in developing countries, increasing farm income, restoring and maintaining above-ground and below-ground biodiversity, corridors between protected forests, as $\mathrm{CH}_{4}$ sinks, maintaining watershed hydrology, and soil conservation. Agroforestry also mitigates the demand for wood and reduces pressure on natural forests. Promoting woodcarving industry facilitates long-term locking-up of carbon in carved wood and new sequestration through intensified tree growing. By making use of local knowledge, equity, livelihood security, trade and industry, can be supported. There is need to support development of suitable policies, assisted by robust country-wide scientific studies aimed at better understanding the potential of agroforestry and ethno forestry for climate change mitigation and human well-being.. It has the ability to enhance the resilience of the system for coping with the adverse impacts of climate change. Agroforestry systems offer important opportunities of creating synergies between both adaptation and mitigation actions. Various authors have carried out studies to estimate carbon stocks in different agroforestry systems in India. Agroforestry systems have the potential to provide significant mitigation options but they require proper management that influences the amount of carbon sequestered. The role of agroforestry practices in climate change mitigation in India can be realized to its full potential by overcoming various technical, financial and institutional barriers. Agroforestry, the practice of introducing trees in farming has played a significant role in enhancing land productivity and improving livelihoods in both developed and developing countries. Although carbon sequestration through afforestation and reforestation of degraded natural forests has long been considered useful in climate change mitigation, agroforestry offers some distinct advantages. The planting of trees along with crops improves soil fertility, controls and prevents soil erosion, controls water logging, checks acidification and eutrophication of streams and rivers, increases local biodiversity, decreases pressure on natural forests for fuel and provides fodder for livestock. 
Table.1 Detailed information about different tree species

\begin{tabular}{|c|c|c|c|c|c|c|}
\hline Potential & $\begin{array}{l}\text { Cultivatio } \\
\text { n }\end{array}$ & Suitable for & Contamination & Productivity & Remediation potential & Uses \\
\hline \multirow[t]{2}{*}{ Species } & method & production in & constraints & & & \\
\hline & & Renfrewshire & & & & \\
\hline Willow & Short & Yes - known to & Can grow on & Fast growing (can & Ecosystem restoration, & Biomass - \\
\hline \multirow[t]{11}{*}{$\begin{array}{l}\text { (Salix } \\
\text { spp.) } \\
\end{array}$} & rotation & $\begin{array}{l}\text { grow in } \\
\text { Scotland. }\end{array}$ & $\begin{array}{l}\text { contaminated } \\
\text { soils; }\end{array}$ & sequester more & phytoremediation & $\begin{array}{l}\text { fuel and } \\
\text { fibre }\end{array}$ \\
\hline & $\begin{array}{l}\text { coppicing } \\
-\end{array}$ & Flood resistant & $\begin{array}{l}\text { resistant to } \mathrm{Cd} \text {, } \\
\mathrm{Cu},\end{array}$ & carbon than & (phytoextraction, & \\
\hline & $\begin{array}{l}\text { rotation 3- } \\
5\end{array}$ & & $\mathrm{Zn}, \mathrm{Ni}, \mathrm{Pb}, \mathrm{Fe}$ & softwoods in a & $\begin{array}{l}\text { phytodegradation, } \\
\text { rhizofiltration }\end{array}$ & \\
\hline & years & & Cultivars/ & growing season); & $\begin{array}{l}\text { phytostabilisation), } \\
\text { reduction in }\end{array}$ & \\
\hline & & & $\begin{array}{l}\text { genotypes vary } \\
\text { in }\end{array}$ & easily propagated. & water/ wind erosion. High & \\
\hline & & & resistance & $\begin{array}{l}\text { Yield 7-12 oven- } \\
\text { dried }\end{array}$ & $\begin{array}{l}\text { accumulator of metals, e.g. } \\
\mathrm{Cd}\end{array}$ & \\
\hline & & & & & $\begin{array}{l}\text { and Zn. Can remediate } \\
\text { many }\end{array}$ & \\
\hline & & & & & organic compounds, e.g. oil & \\
\hline & & & & & & \\
\hline & & & & & & \\
\hline & & & & & & \\
\hline Poplar & Short & Yes - known to & Can grow on & Yield very site- & $\begin{array}{l}\text { Hyper accumulator of } \\
\text { metals, }\end{array}$ & Biomass - \\
\hline (Populus & rotation & grow in Scotland & $\begin{array}{l}\text { contaminated } \\
\text { soils }\end{array}$ & dependent and can & e.g. $\mathrm{Cd}$ and $\mathrm{Zn}$ & $\begin{array}{l}\text { fuel and } \\
\text { fibre }\end{array}$ \\
\hline \multirow[t]{3}{*}{ spp.) } & coppicing & & & $\begin{array}{l}\text { out-perform } \\
\text { willow on }\end{array}$ & (phytoaccumulation) and & \\
\hline & $\begin{array}{l}\text { rotation } 4- \\
5\end{array}$ & & & some sites & $\begin{array}{l}\text { promotes phytostabilisation } \\
\text { in }\end{array}$ & \\
\hline & years & & & & rhizosphere & \\
\hline Elephant & Short & Grows well in & Unknown -more & Higher yields on & $\begin{array}{l}\text { May reduce nutrient loss } \\
\text { from }\end{array}$ & Biomass \\
\hline Grass & rotation & England; not & research required & moisture retentive & $\begin{array}{l}\text { soils by uptake and storage } \\
\text { in }\end{array}$ & \\
\hline $\begin{array}{l}\text { (Miscanth } \\
\mathbf{u}\end{array}$ & cropping & $\begin{array}{l}\text { known in } \\
\text { Scotland. }\end{array}$ & & $\begin{array}{l}\text { soils which warm } \\
\text { up }\end{array}$ & $\begin{array}{l}\text { rhizomes, decreasing } \\
\text { pollution }\end{array}$ & \\
\hline $\mathbf{s}$ & annual & $\begin{array}{l}\text { Wide range of } \\
\text { soil }\end{array}$ & & quickly in spring. & of water environment (not & \\
\hline \multirow[t]{3}{*}{ giganteus) } & harvesting & types & & Yield $12-15$ oven & $\begin{array}{l}\text { usually applicable to } \\
\text { brownfield }\end{array}$ & \\
\hline & of grass & & & $\begin{array}{l}\text { dried tonnes /ha } \\
(15-\end{array}$ & $\begin{array}{l}\text { sites); reduction in soil } \\
\text { erosion. }\end{array}$ & \\
\hline & & & & $18 \mathrm{t}$ fresh/ha) & & \\
\hline & & & & & & \\
\hline & & & & & & \\
\hline
\end{tabular}




\begin{tabular}{|c|c|c|c|c|c|c|}
\hline Potential & $\begin{array}{l}\text { Cultivatio } \\
\mathrm{n}\end{array}$ & Suitable for & Contamination & Productivity & Remediation potential & Uses \\
\hline \multirow[t]{2}{*}{ Species } & method & production in & constraints & & & \\
\hline & & Renfrewshire & & & & \\
\hline Aspen & Short & Yes - known to & $\begin{array}{l}\text { American } \\
\text { (Populus }\end{array}$ & $\begin{array}{l}\text { Fast } \quad \text { growing; } \\
\text { easily }\end{array}$ & $\begin{array}{l}\text { High accumulator of metals, } \\
\text { e.g. }\end{array}$ & Biomass, \\
\hline $\begin{array}{l}\text { (Populus } \\
\text { Pop }\end{array}$ & rotation & $\begin{array}{l}\text { grow in } \\
\text { Scotland. }\end{array}$ & tremula) and & propagated Yield - & $\begin{array}{ll}\mathrm{Cd} & \text { and } \\
\text { (phytoaccumulation) }\end{array}$ & Timber \\
\hline \multirow[t]{9}{*}{ tremula) } & forestry - & $\begin{array}{l}\text { Only native } \\
\text { poplar }\end{array}$ & $\begin{array}{l}\text { European } \\
\text { (Populus }\end{array}$ & mean annual & $\begin{array}{l}\text { and } \\
\text { phytostabilisation }\end{array}$ & (though little \\
\hline & tree & $\begin{array}{l}\text { grows under } \\
\text { range }\end{array}$ & tremuloides) & $\begin{array}{l}\text { increment } \\
12 \mathrm{~m}^{3} / \mathrm{ha} /\end{array}$ & in rhizosphere & $\begin{array}{l}\text { production } \\
\text { in }\end{array}$ \\
\hline & & of climatic & $\begin{array}{l}\text { known to grow } \\
\text { on }\end{array}$ & $\mathrm{yr}$ (same as & & Scotland); \\
\hline & & $\begin{array}{l}\text { conditions } \\
\text { (stunted }\end{array}$ & $\begin{array}{l}\text { contaminated } \\
\text { soils, }\end{array}$ & $\begin{array}{l}\text { sycamore/ ash/ } \\
\text { birch) }\end{array}$ & & higher wood \\
\hline & & when stressed) & $\begin{array}{l}\text { and shale } \\
\text { quarries, }\end{array}$ & & & density than \\
\hline & & & $\begin{array}{l}\text { coal spoil, low } \\
\text { pH, }\end{array}$ & & & poplar \\
\hline & & & heavy metals, & & & \\
\hline & & & PAHs. & & & \\
\hline & Short & Yes - known to & Can grow on & Fast growing Yield & Uptake of $\mathrm{Ca}, \mathrm{Cu}$ and $\mathrm{Mn}$ & potential \\
\hline \multirow[t]{6}{*}{ (Betula) } & rotation & $\begin{array}{l}\text { grow in } \\
\text { Scotland. }\end{array}$ & $\begin{array}{l}\text { contaminated } \\
\text { soils }\end{array}$ & mean annual & reported & veneer, \\
\hline & forestry (8- & Pioneer species, & & $\begin{array}{l}\text { increment } \\
12 \mathrm{~m}^{3} / \mathrm{ha} /\end{array}$ & & plywood, \\
\hline & 20 years & rapidly colonise & & $\mathrm{yr}$ (same as & & biomass/ \\
\hline & rotation) & open ground & & sycamore/ash/ & & $\begin{array}{l}\text { landscaping } \\
\text { ? }\end{array}$ \\
\hline & & following & & poplar) & & \\
\hline & & disturbance & & & & \\
\hline Hazel & Woodland, & Yes - grows in & Can grow on & $\begin{array}{ll}\begin{array}{l}\text { Fast } \\
\text { (similar }\end{array} & \text { growing } \\
\end{array}$ & Unknown & Nut \\
\hline (Corylus & orchard, & Scotland. & $\begin{array}{l}\text { contaminated } \\
\text { soils }\end{array}$ & to birch) & & production; \\
\hline \multirow[t]{4}{*}{ avellana) } & tree belts & & & & & $\begin{array}{l}\text { amenity } \\
\text { value, }\end{array}$ \\
\hline & & & & & & biodiversity, \\
\hline & & & & & & potential \\
\hline & & & & & & biomass? \\
\hline Oak & Woodland, & Yes - grows in & Can grow on & Slow growing & Unknown & Amenity \\
\hline \multirow[t]{5}{*}{ (Quercus) } & tree belts, & Scotland. & $\begin{array}{l}\text { contaminated } \\
\text { soils }\end{array}$ & & & value, \\
\hline & long-term & & & & & biodiversity \\
\hline & forestry & & & & & $\begin{array}{l}\text { (lesser } \\
\text { extent }\end{array}$ \\
\hline & & & & & & timber \\
\hline & & & & & & production) \\
\hline
\end{tabular}




\section{Transformation Pathways}

\begin{tabular}{|l|l|l|l|}
\hline No. & Process & Mechanism & Contaminant \\
\hline $\mathbf{1}$ & Phytoextraction & Hyper-accumulation & Inorganics \\
\hline $\mathbf{2}$ & Phytovolatilization & Volatilization by leaves & Organics/Inorganics \\
\hline $\mathbf{3}$ & Rhizofiltration & Rhizosphere accumulation & Organics/Inorganics \\
\hline $\mathbf{4}$ & Phytotransformation & Degradation in plant & Organic \\
\hline $\mathbf{5}$ & Phytostabilisation & Complexation & Inorganic \\
\hline
\end{tabular}

\section{Transgenic plants and phytoremediation}

\begin{tabular}{|l|l|l|l|l|l|}
\hline S.no & Pollutant(s) & Transgenic & Gene source & Foreign gene or DNA & Reference \\
\hline $\mathbf{1}$ & $\mathrm{Cd}$ & B. juncea & E. coli & gshI & Zhu et al., 1999b \\
\hline $\mathbf{2}$ & $\mathrm{Cd}$ & B. juncea & E. coli & gshII & Zhu et al., 1999a \\
\hline $\mathbf{3}$ & $\mathrm{Cd}, \mathrm{Pb}$ & A. thaliana & S. cerevisiae & YCF1 & Song et al., 2003 \\
\hline $\mathbf{4}$ & $\mathrm{Cd}, \mathrm{Cu}, \mathrm{Pb}$ & B. Juncea & E. coli & gshI & Bennett et al., 2003 \\
\hline $\mathbf{5}$ & $\mathrm{Hg}(\mathrm{II})$ & Arabidopsis & Bacteria & merA & Heaton et al., 1998 \\
\hline $\mathbf{6}$ & $\mathrm{Hg}(\mathrm{II})$ & L. tulipifer & Bacteria & merA & Rugh et al., 1998 \\
\hline $\mathbf{7}$ & $\mathrm{MeHg}$ & A. thaliana & E. coli & merApe9 & Rugh et al., 1996 \\
\hline $\mathbf{8}$ & $\mathrm{MeHg}$ & A. thaliana & Bacteria & merBpe & Bizily et al., 1999 \\
\hline $\mathbf{9}$ & $\mathrm{MeHg}$ & A. thaliana & Bacteria & merA, merB & Bizily et al., 2000 \\
\hline $\mathbf{1 0}$ & $\mathrm{MeHg}$ & Arabidopsis & Bacteria & merB & Bizily et al., 2003 \\
\hline $\mathbf{1 1}$ & $\mathrm{PMA}$ & N. tabaccum & Bacteria & merA, merB & Ruiz et al., 2003 \\
\hline $\mathbf{1 2}$ & ACET, ME & Populus & Bacteria & & Gullner et al., 2001 \\
\hline $\mathbf{1 3}$ & GTN, TNT & N. tabaccum & Bacteria & & French et al., 1999 \\
\hline $\mathbf{1 4}$ & PCP & N. tabaccum & C. versicolor & & Iimura et al., 2002 \\
\hline $\mathbf{1 5}$ & As & B. napus & E. cloacae & & Nie et al., 2002 \\
\hline
\end{tabular}

It also has the ability to enhance the resilience of the system for coping with the adverse impacts of climate change.

The effectiveness of agroforestry systems in storing carbon depends on both environmental and socio-economic factors; in humid tropics, agroforestry systems have the potential to sequester over $70 \mathrm{Mg} / \mathrm{ha}$ in the top $20 \mathrm{~cm}$ of the soil. The carbon storage capacity in agroforestry varies across species and geography. Further, the amount of carbon in any agroforestry system depends on the structure and function of different components within the systems put into practice. The fact that agroforestry systems can function as both source and sink of carbon has been presented in literature. There is also clear evidence to suggest that the type of agroforestry system greatly influences the source or sink role of the trees. For example, agri-silvicultural systems where trees and crops are grown together are net sinks while agro silvipastoral systems are possibly sources of GHGs. Practices like tillage, controlled burning, manuring, application of chemical fertilizers and frequent soil disturbance can lead to significant emissions of GHGs. According to the IPCC agroforestry systems offer important opportunities of creating synergies between both adaptation and mitigation actions with a technical mitigation potential of 1.1-2.2 $\mathrm{PgC}$ in terrestrial ecosystems over the next 50 years. Additionally, 630 Mha of unproductive croplands and grasslands could be converted to agroforestry representing a carbon sequestration potential of $391,000 \mathrm{MgC} / \mathrm{yr}$ by 2010 and 586,000 $\mathrm{MgC} / \mathrm{yr}$ by 2040. The carbon in the aboveground and belowground 
biomass in an agroforestry system is generally much higher than the equivalent land use without trees (i.e. crop land without any trees).The estimates of potential for carbon storage in different kinds of agroforestry systems are provided In Southeast Asia, agrisilvicultural systems have the capacity to store 12-228 $\mathrm{MgC} / \mathrm{ha}$ in humid tropical lands and $68-81 \mathrm{MgC} / \mathrm{ha}$ in dry lowlands. Highest potential for carbon storage can be observed for North American silvi pastoral systems with a range of $90-198 \mathrm{MgC} / \mathrm{ha}$. The potential to sequester carbon in aboveground components in agroforestry systems is estimated to be $2.1 \times 10^{9} \mathrm{MgCyear}^{-1}$ in tropical and $1.9 \times 10^{9} \mathrm{MgCyear}^{-1}$ in temperate biomes. Agroforestry systems can have indirect effects on carbon sequestration as it helps decrease pressure on natural forests that are the largest sinks of terrestrial carbon, they also conserve soils and thus enhance carbon storage in trees and soils. Effects of agroforestry practices on the soil carbon pool indicated a rate of increase by $2-3 \mathrm{MgC} / \mathrm{ha} / \mathrm{yr}$. Estimations of carbon sequestration potential in various studies report an estimated potential of 6.3GtC and 0.7-1.6 GtC. The carbon sequestration potential of agroforestry systems has been established theoretically; however field measurements to validate these concepts are limited. The inherent variability in the estimates of potential carbon storage in agroforestry systems and the lack of uniform methodologies has made comparisons difficult. Few studies of specific agroforestry practices have proved potential for carbon sequestration.

Phytoremediation is a fast developing field, since last ten years lot of field application were initiated all over the world, it includes Phytoremediation of Organic, Inorganic and Radionuclides. This sustainable and inexpensive process is fast emerging as viable alternative to conventional remediation methods, and will be most suitable for a developing country like India. Most of the studies have been done in developed countries and knowledge of suitable plants is particularly limited in India. In India commercial application of Phytoremediation of soil Heavy metal or Organic compounds is in its earliest phase. Fast growing plants with high biomass and good metal uptake ability are needed. In most of the contaminated sites hardy, tolerant, weed species exist and phytoremediation through these and other non-edible species can restrict the contaminant from being introduced into the food web. However, several methods of plant disposal have been described but data regarding these methods are scarce. Composting and compaction can be treated as pre-treatment steps for volume reduction, but care should be taken to collect leachate resulting from compaction. Between the two methods that significantly reduce the contaminated biomass, incineration seems to be least time consuming and environmentally sound than direct burning or ashing.

\section{References}

Albrecht A, Kandji ST 2003. Carbon sequestration in tropical agroforestry systems. Agriculture, Ecosystems and Environment 99: 15-27.

Anderson, T. A., Guthrie, E. A., and Walton, B. T. 1993. Bioremediation in the rhizosphere. Environ. Sci. Technol. 27: 2630-2636.

Assaf, N.A., and Turco, R. F. 1994. Accelerated biodegradation of atrazine by a microbial consortium is possible in culture and soil. Biodeg.5: 29-35.

Bennett, L. E., Burkhead, J. L., Hale, K. L., Terry, N., Pilon, M., and Pilon-Smits, E. A. H. 2003. Analysis of transgenic Indian mustard plants for phytoremediation of metal-contaminated mine tailings. J. Environ. Qual. 32: 432-440.

Bhadra, R., Wayment, D. G., Williams, R. K., Barman, S. N., Stone, M. B., Hughes, J. B., and Shanks, J. V. 2001. Studies on plantmediated fate of the explosives RDX and 
HMX. Chemosphere 44: 1259-1264

Bizily, S. P., Kim, T., Kandasamy, M. K., and Meagher, R. B. 2003. Sub-cellular targeting of methylmercury lyase enhances its specific activity for organic mercury detoxification in plants. Plant Physiol. 131: 463-471.

Bizily, S. P., Rugh, C. L., and Meagher, R. B. 2000. Phytodetoxification of hazardous organomercurials by genetically engineered plants. Nat. Biotech.18: 213-215

Bizily, S. P., Rugh, C. L., Summers, A. O., and Meagher, R. B. 1999. Phytoremediation of methylmercury pollution: merB expression in Arabidopsis thaliana confers resistance to organomercurials. Proc. Natl. Acad. Sci. USA96: 6808-6813.

Boyajian, G. E., and Carreira, L. H. 1997. Phytoremediation: A clean transition from laboratory to marketplace? Nat. Biotechnol. 15: $127-128$.

Brown S, Sathaye J, Cannell M, Kauppi P 1996. Management of forests for mitigation of greenhouse gas emissions. In: Watson RT, Zinyowera MC, Moss RH (eds.), Climate Change 1995: Impacts, Adaptations and Mitigation of Climate Change: ScientificTechnical Analyses. Contribution of Working Group II to the Second Assessment Report of the Intergovernmental Panel on Climate Change, Cambridge University Press, Cambridge and New York, USA.

Dixon RK 1995. Agroforestry systems: sources or sinks of greenhouse gases? Agroforestry Systems 31: 99-116.

French, C. E., Rosser, S. J., Davies, G. J., Nicklin, S., and Bruce, N. C. 1999.Biodegradation of explosives by transgenic plants expressing pentaerythritoltetra nitrate reductase. Nat. Biotechnol. 17: 491-494.

Garg VK 1998. Interaction of tree crops with a sodic soil environment: Potential for rehabilitation of degraded environments. Land Degradation and Development 9: 8193.

Gullner, G., K “omives, T., and Rennenberg, H. 2001. Enhanced tolerance oftransgenic poplar plants overexpressing $\gamma-$ glutamylcysteine synthetase to-wards chloroacetanilide herbicides. J. Exp. Bot.
52: 971-979.

Gwozdz, E. A., and Kopyra, M. 2003. Plant cell responses to heavy metals biotechnological aspects. Biotechnologia 3: 107-123

Gwozdz, E. A., and Kopyra, M. 2003. Plant cell responses to heavy metals biotechnological aspects. Biotechnologia3: 107-123.

Heaton, A. C. P., Rugh, C. L., Wang, N.-J., and Meagher, R. B. 1998. Phytoremedation of mercury- and methylmercury-polluted soils using genetically engineered plants. J. Soil Contam. 7: 497-509.

Hoagland, R. E., Zablotowicz, R. M., and Hall, J. C. 2001. Pesticide metabolism in plants and microorganisms: An overview. In: Pesticide Biotransformationin Plants and Microorganisms: Similarities and Divergences, pp. 2-27. Hall

Iimura, Y., Ikeda, S., Sonoki, T., Hayakawa, T., Kajita, S., Kimbara, K., Tatsumi, K., and Katayama, Y. 2002. Expression of a gene for Mn-peroxidase fromCoriolus versicolor in transgenic tobacco generates potential tools for phy-toremediation. Appl. Microbiol. Biotechnol. 59: 246-251.

Indu K Murthy", Mohini Gupta, Sonam Tomar Carbon Sequestration Potential of Agroforestry Systems in India

Kandji ST, Verchot LV, Mackensen J, Boye A, Van NM, et al., 2006. Opportunities for linking climate change adaptation and mitigation through agroforestry systems: World Agroforestry into the Future, Garrity DP, Okono A, Grayson M, Parrott S: 113121. World Agroforestry Centre (ICRAF), ISBN, Nairobi, Kenya.

Knox, A. S., Kaplan, D. I, Hinton, T. G., Sharitz, R., and Serkiz, S. 2001. Soil remediation by combining phytoextraction and mineral immobilization. 2000, International Symposium and Exhibition on Environmental Contamination in Central \& Eastern Europe, Proceedings, Sept. 12-14, 2000 (2001), Meeting Date 2000, pp. 8793, Prague, Czech Republic.

Knox, A. S., Kaplan, D. I, Hinton, T. G., Sharitz, R., and Serkiz, S. 2001. Soil remediation by combining phytoextraction and mineral immobilization. 2000, International 
Symposium \& Exhibition on Environmental Contamination in Central \& Eastern Europe, Proceedings, Sept. 12-14, 2000 (2001), Meeting Date 2000, pp. 8793, Prague, Czech Republic.

Kochian L.V. 1993. Zinc absorption from hydroponic solutions by plant roots. In: Zinc in Soils and Plants, pp. 45-57. Robson, A. D. Ed., Dordrecht, Netherlands: Kluwer

Li, Y.-M., Chaney, R. L., Angle, J. S., and Baker, A. J. M. 2000. Phytoremediation of heavy metal contaminated soils. Environ. Sci. Poll. Con. Series 22: 837-857.

Makundi WR, Sathaye JA 2004. GHG mitigation potential and cost in tropical forestryrelative role for agroforestry. Environment, Development and Sustainability 6: 235-260.

Marschner, H. 1995. Mineral Nutrition of Higher Plants. Academic Press, NewYork, NY. McCutcheon, S. C., and Schnoor, J. L. 2003.Phytoremediation: Transformation and Control of Contaminants. John Wiley and Sons, Inc., Hoboken, NJ.

Montagnini F, Nair PKR 2004. Carbon sequestration: An underexploited environmental benefit of agroforestry systems. Agroforestry Systems 61: 281295.

Mutuo PK, Cadisch G, Albrecht Palm CA, Verchot L 2005. Potential of agroforestry for carbon sequestration and mitigation of greenhouse gas emissions from soils in the tropics. Nutrient Cycling in Agroecosystems 71: 43-54.

Newaj R, Dhyani SK 2008. Agroforestry for carbon sequestration: Scope and present status. Indian Journal of Agroforestry 10: 19.

Nie, L., Shah, S., Rashid, A., Burd, G I., Dixon, D. G., and Glick, B. R. 2002.Phytoremediation of arsenate contaminated soil by transgenic canola andthe plant growth-promoting bacterium Enterobacter cloacae CLA2. Plant Physiol. Biochem. 40: 355-361

Oelbermann M, Voroney RP, Gordon AM (2004) Carbon sequestration in tropical and temperate agroforestry systems: a review with examples from Costa Rica and southern Canada Agriculture. Ecosystems and Environment 104: 359-377.

Pilon-Smits, E. A. H., De Souza, M. P., Hong, G., Amini, A., Bravo, R. C., Payabyab, S. T., and Terry, N. 1999. Wetlands and aquatic processes: Selenium volatilization and accumulation by twenty aquatic plant species. J. Environ. Qual. 28: 1011-1018.

Pilon-Smits, E. A. H., De Souza, M. P., Hong, G., Amini, A., Bravo, R. C., Payabyab, S. T., and Terry, N. 1999. Wetlands and aquatic processes: Selenium volatilization and accumulation by twenty aquatic plant species. J.Environ. Qual. 28: 1011-1018.

Raskin, I., and Kumar, P. B. A. N. 1994. Bioconcentration of heavy metals by plants.Curr.Opin.Biotechnol. 5: 285-290.

Raskin, I., and Kumar, P. B. A. N. 1994. Bioconcentration of heavy metals by plants.Curr.Opin.Biotechnol.5: 285-290.

Roshetko JM, Delaney M, Hairiah K, Purnomosidhi, P 2002. Carbon stocks in Indonesian homegarden systems: Can smallholder systems be targeted for increased carbon storage? American Journal of Alternative Agriculture 17: 138148.

Rugh, C. L., Senecoff, J. F., Meagher, R. B., and Merkle, S. A. 1998. De-velopment of transgenic yellow poplar for mercury phytoremediation. Nat. Biotechnol. 16: 925-928.

Rugh, C. L., Wilde, H. D., Stack, N. M., Thompson, D. M., Summers, A O., and Meagher, R B. 1996. Mercuric ion reduction and resistance in transgenic Arabidopsis thaliana plants expressing a modified bacterial mer Agene. Proc. Nat. Acad. Sci. 93: 3182-3187.

Ruiz, O. N., Hussein, H. S., Terry, N., and Daniell, H. 2003. Phytoremediation of organomercurial compounds via chloroplast genetic engineering. Plant Physiol. 132: 1344-1352.

Schroeder P (1993) Agroforestry systems: integrated land use to store and conserve carbon. Climate Research 3: 53-60.

Sekhar, K. C., Kamala, C. T., Chary, N. S., Sastry, A. R. K., Rao, T. N., and Vairamani, M. 2004. Removal of lead from aqueous solutions using an immobilized biomaterial derived from a plant biomass. J. Haz. Mat. 
108: 111-117.

Sekhar, K. C., Kamala, C. T., Chary, N. S., Sastry, A. R. K., Rao, T. N., and Vairamani, M. 2004. Removal of lead from aqueous solutions using an immobilized biomaterial derived from a plant biomass. J. Haz. Mat. 108: 111-117.

Song, W.-Y., Sohn, E. J., Martinoia, E., Lee, Y. J, Yang, Y.-Y., Jasinski, M., Forestier, C., Hwang, I., and Lee, Y. 2003. Engineering tolerance and accumulation of lead and cadmium in transgenic plants. Nat. Biotechnol. 21: 914-919.

Sparks, D. L. 1995.Environmental Soil Chemistry. Academic Press, San Diego, CA

Takimoto A, Nair PKR, Nair VD 2008. Carbon stock and sequestration potential of traditional and improved agroforestry systems in the West African Sahel. Agriculture, Ecosystems and Environment
125: 159-166.

Trexler MC, Haugen C, 1994. Keeping it Green:

Tropical Forestry Opportunities for Mitigating Climate Change. World Resources Institute, Washington DC, PP. 52.

Zhu, Y. L., Pilon-Smits, E. A. H., Tarun, A. S., Weber, S. U., Jouanin, L., and Terry, N. 1999b. Cadmium tolerance and accumulation in Indian mustard is enhanced by overexpressing $\gamma$-glutamylcysteine synthetase. Plant Physiol.121: 1169-1177.

Zhu, Y. L., Pilon-Smits, E. A.H., Jouanin, L., and Terry, N. 1999a. Overex-pression of glutathione synthetase in Indian mustard enhances cadmium accumulation and tolerance. Plant Physi.

\section{How to cite this article:}

Khanzad Gul Zazai, Owais Ali Wani, Aamina Ali and Mamta Devi. 2018. Phytoremediation and Carbon Sequestration Potential of Agroforestry Systems: A Review. Int.J.Curr.Microbiol.App.Sci. 7(01): 2447-2457. doi: https://doi.org/10.20546/ijcmas.2018.701.295 